\title{
PENGEMBANGAN MOBILE LEARNING BERBASIS ANDROID MATERI RECOUNT TEXT KELAS X BAHASA
}

\author{
Ahmad Ilman, Sulthoni, Agus Wedi \\ Teknologi Pendidikan, Fakultas Ilmu Pendidikan, Universitas Negeri Malang. \\ Jl. Semarang No.5, Malang, 65145, Indonesia.
}

\section{Article History}

Received: 28 November 2020, Accepted: 01 April 2021, Published: 20 Februari 2022

\begin{abstract}
Abstrak
Penelitian ini bertujuan guna menghasilkan aplikasi mobile learning berbasis android yang layak digunakan dalam pembelajaran berdasarkan ahli materi, ahli media, dan pengguna. Aplikasi mobile learning berbasis android tersebut berisi materi recount text yang terdapat pada mata pelajaran Sastra Inggris untuk kelas $\mathrm{X}$ bahasa. Penelitian pengembangan ini dilaksanakan mengikuti model pengembangan dari Lee \& Owens yang terdiri 5 tahap, yaitu Analisis / Penilaian yang terdiri atas 2 bagian yaitu analisis kebutuhan dan analisis Front-End, Desain, Pengembangan, Implementasi, dan Evaluasi. Produk awal produk aplikasi akan diuji coba oleh ahli media dan ahli materi sebelum dilakukan uji coba ke siswa. Uji coba pemanfaatan produk aplikasi dilakukan oleh 17 siswa kelas X Bahasa. Hasil penelitian menunjukkan bahwa produk aplikasi mobile learning berbasis android materi recount text dapat dinyatakan layak untuk digunakan dalam pembelajaran berdasarkan tanggapan ahli media, ahli materi dan pengguna dengan rata-rata penilaian mencapai skor 3,5 dan masuk kedalam kategori "Sangat Baik".
\end{abstract}

Kata kunci: Mobile Learning; Android; Recount Text; Bahasa Inggris

\begin{abstract}
This study aims to produce an Android-based mobile learning application that is suitable for use in learning based on material experts, media experts, and users. The Android-based mobile learning application contains recount text material contained in English Literature subjects for class $X$ language. This development research was carried out following the development model of Lee \& Owens which consists of 5 stages, namely Analysis / Assessment which consists of 2 parts, namely needs analysis and Front-End analysis, Design, Development, Implementation, and Evaluation. The initial product of the application product will be tested by media experts and material experts before being tested on students. The trial of the use of the application product was carried out by 17 students of class X Bahasa. The results showed that the mobile learning application product based on android recount text material can be declared suitable for use in learning based on the responses of media experts, material experts and users with an average score of 3.5 and is included in the "Very Good" category.
\end{abstract}

Keyword: Mobile Learning; Android; Recount Text; English Subject 


\section{PENDAHULUAN}

Bahasa Inggris adalah bahasa internasional yang dipergunakan di banyak negara selaku alat komunikasi, dimana berbagai hal di dunia memepergunakan bahasa Inggris selaku alat pengantarnya. Di tahun 2020 melalui kelajuan teknologi dan heterogenitas masyarakat dunia yang majemuk, bahasa Inggris mutlak perlu dikuasai karena menjadi alat komunikasi di berbagai negara. Berdasarkan hal tersebut, keterampilan berbahasa Inggris mutlak perlu dikuasai. Di Indonesia sendiri kedudukan bahasa asing khususnya negara Inggris sudah seperti bahasa kedua, yang mana digunakan dalam banyak hal di kehidupan.

Sekolah merupakan tempat siswa mengembangkan berbagai kemampuan mereka dalam banyak hal. Bahasa Inggris sendiri telah diajarkan di sekolah sejak tingkat Sekolah Dasar (SD) hingga tingkat Sekolah Menengah Atas (SMA). Hal ini dirasa perlu guna membiasakan peserta didik untuk lancar berbahasa Inggris. Beranjak ke jenjang SMA, bahasa Inggris termasuk ke dalam salah satu mata pelajaran yang dinilai perlu untuk dipelajari, terutama pada jurusan bahasa yang ada di dalam SMAN 3 Lamongan. Dalam era yang semaju ini, perihal belajar bahasa asing tidak lagi menjadi permasalahan sulit karena sudah tersedia banyak sekali kursus, aplikasi, bahkan website yang memberikan kemudahan dalam hal belajar bahasa asing dan dapat diakses dimana saja sehingga sekolah bukan satu satunya tempat siswa mengasah kemampuan berbahasa Inggrisnya tapi, bukan berarti juga bahwa belajar Bahasa asing khususnya bahasa Inggris dapat diklasifikasikan sebagai perkara yang mudah. Kompleksitas kosakata dan tenses menjadi ketakutan tersendiri bagi sebagian peserta didik dalam mempelajari bahasa Inggris. Hal ini diperkuat dengan banyaknya siswa Indonesia memiliki nilai berada di bawah kriteria ketuntasan minimal (KKM) dalam mata pelajaran bahasa Inggris (Rismadewi, 2019). Selain kompleksitas kosakata dan implementasi tenses, perbedaan aksen yang dipakai di tiap negara juga menjadi faktor lainnya yang menghambat siswa dalam beberapa ujian yang mengikutsertakan listening test sebagai bagian dari ujian (Kwon, 2019).

Berdasar pada observasi yang dilaksanakan pengembang di SMAN 3 Lamongan khususnya kelas $\mathrm{x}$ bahasa, Sastra Inggris dinilai sebagai mata pelajaran yang dirasa sulit oleh siswa. Pengembang memilih pelajaran sastra Inggris khususnya materi recount text karena pembelajarannya masih menitikberatkan kepada guru, sehingga berakibat pada cara mengajar siswa dengan kecenderungan pasif dalam menyerap materi. Permasalahan tersebut berbanding lurus terhadap kompetensi siswa dalam berbicara bahasa inggris sehari hari, yang mana bila siswa tidak memiliki banyak variasi kosakata dan mengerti tata bahasa dalam bahasa Inggris maka, akan berdampak pada kemampuan speaking dan listening mereka. Selain permasalahan pada tenses dan verb, kurangnya minat siswa berkaitan dengan pelajaran berupa pengulangan kembali di rumah atau refleksi diri menjadi alasan penghambat perkembangan siswa.

Seiring pembelajaran berlangsung, ditemukan fakta di lapangan bahwa guru pun jarang menggunakan media dalam penyampaian materi. Guru biasanya hanya menuliskan rumus tenses dan tingkatan verb pada papan tulis. Penyebab menurunnya minat siswa disinyalir karena kebanyakan siswa kurang tertarik dengan mata pelajaran sastra Inggris. Mayoritas siswa kurang terdorong maupun termotivasi terhadap pembelajaran karena dianggap kurang menarik. Berdasarkan masalah tersebut, penggunaaan media sebagai tambahan akan menjadi sebuah bentuk inovasi baru guna meningkatkan tingkat pemahaman siswa dalam pelajaran tersebut.

Berdasar pada temuan di lapangan mengenai masalah terkait media sebagai bagian dari pembelajaran serta tanggung-jawab guru dalam mencocokkan karakteristik peserta didik dengan model dan metode sehingga tercapai tujuan belajar yang efektif serta cocok dengan satu kawasan teknologi pendidikan yaitu aspek pemanfaatan. Menurut AECT 1994, ada 5 kawasan teknologi 
pendidikan terdiri atas : 1) Desain, 2) Pengembangan, 3) Pemanfaatan, 4) Pengelolaan, 5) Evaluasi (Prawiradilaga, 2012). Kawasan pemanfaatan merupakan sebuah aktivitas dalam memberdayagunakan proses serta sumber yang digunakan dalam belajar. Kawasan pemanfaatan seorang teknolog pendidikan mempunyai berbagai tanggung jawab mencocokkan pebelajar dengan model serta strategi yang bersifat spesifik, menyiapkan pebelajar supaya dapat berinteraksi melalui bahan dan aktivitas pilihannya, memberi pengarahan selama proses kegiatan berlangsung, memberi penilaian atas tercapainya hasil yang diharapkan oleh pebelajar, serta memasukkan kegiatan sesuai prosedur organisasi yang berlangsung. Berkenaan terkait permasalahan pada kelas $\mathrm{X}$ bahasa SMAN 3 Lamongan, peneliti memberi kesimpulan bahwa diperlukannya media pembelajaran tambahan sebagai penunjang pembelajaran mata pelajaran sastra Inggris.

Media pembelajaran merupakan komponen dari sumber belajar berbentuk fisik berisi materi instruksional dengan sifat dapat merangsang siswa untuk belajar (Sutirman, 2013:15). Menurut Sumanto \& Seken (2012:15) pengertian media pembelajaran merupakan sarana guna memberikan rangsangan kepada siswa agar pembelajaran berjalan lancar. Menurut pendapat dari dua ahli yang telah dipaparkan dapat diambil kesimpulan bahwasanya kehadiran media pembelajaran dapat merangsang keinginan belajar siswa sekaligus mempermudah siswa dalam memahami suatu materi. Dalam suatu proses pembelajaran, menurut Usman (2006:11) guru seharusnya memiliki pemahaman yang memadai tentang penggunaan media pembelajaran. Selain berbentuk cetak, media pembelajaran memiliki bermacam macam bentuk seperti media audio visual berupa film maupun video, media berbasis komputer berupa video motion graphic, dan berbentuk aplikasi pembelajaran yang dapat dioperasikan secara mobile.

Mobile Learning dapat diartikan sebuah bentuk dari media dengan memanfaatkan perangkat teknologi yang bergerak seperti smartphone, tablet, Laptop, dan lain-lain (Riady, 2016). Dengan menggunakan $r$, pembelajaran tidak lagi terpaku pada kelas serta kehadiran guru di dalamnya tapi, siswa dapat belajar dimanapun dan kapanpun tanpa perlu didampingi oleh guru. Penggunaan sistem seperti itu memberi dampak yaitu siswa lebih antusias serta termotivasi ketika proses pembelajaran serta siswa dapat memiliki pengetahuannya sesuai dengan kemampuannya. Platform mobile learning yang paling banyak digunakan masyarakat Indonesia di era ini adalah android. Android merupakan platform yang terbuka atu open source sehingga siapapun bebas mengembangkannya guna tujuan dalam pembelajaran maupun tujuan pribadi (Fitriahadi, 2020). Pengembang beralasan menggunakan platform android sebagai platform mobile learning karena di SMAN 3 Lamongan siswanya banyak yang memiliki smartphone android namun hanya dipergunakan terkait keperluan SMS, telepon, social media, dan bermain game. Sehingga memanfaatkan smartphone sebagai media dalam proses pembelajaran diharapkan dapat menarik minat serta perhatian siswa agar belajar dengan giat dan mengalihkan mereka dari kegiatan di luar konteks belajar.

Berdasarkan hasil dari penelitian terdahulu yang dirujuk sebagai referensi seperti penelitian dari Surahman \& Surjono (2017) menghasilkan produk Adaptive Mobile Learning dinyatakan layak dan terbukti dapat mendukung proses blended learning. Peningkatan skor sebesar 3,42. Referensi selanjutnya diperoleh dari penelitian (A.Rahardjo, 2019) Media sebagai penerapan mobile learning dinyatakan valid serta efektif. Hasil persentase menunjukkan angka sebesar $95,65 \%$.

Berdasarkan latar belakang masalah di atas, pengembang bermaksud mengembangkan aplikasi berbentuk mobile learning berbasis android mata pelajaran sastra Inggris materi recount text dengan judul Pengembangan Mobile Learning Berbasis Android Materi Recount Text Kelas X 
Bahasa SMAN 3 Lamongan. Dengan dilakukan pembelajaran ini, diharapkan siswa mampu memahami penjelasan materi serta lebih termotivasi dalam belajar.

\section{METODE}

Rancangan penelitian ini mencakup keseluruhan prosesi pengembangan tersruktur berdasar pada metode yang telah digunakan. Hasil produk yang tercipta dari proses pengembangan ini berupa aplikasi android yang mendukung pembelajaran dengan mobile atau bergerak pada materi recount text untuk kelas $\mathrm{X}$ penjurusan bahasa yang ada di dalam SMAN 3 Lamongan. Pengembangan aplikasi ini menggunakan web-based apps yaitu Thunkable X.

Metode yang digunakan merupakan metode pengembangan Lee \& Owens (2004). Alasan menggunakan metode ini karena didalamnya terdapat rincian tahapan yang lengkap, dimulai dari analisis dan penilaian, desain, pengembangan, implementasi, dan evaluasi yang dirasa cocok sebagai metode guna pengembangan aplikasi dengan basis android yang mendukung pembelajaran mobile atau bergerak pada materi recount text.

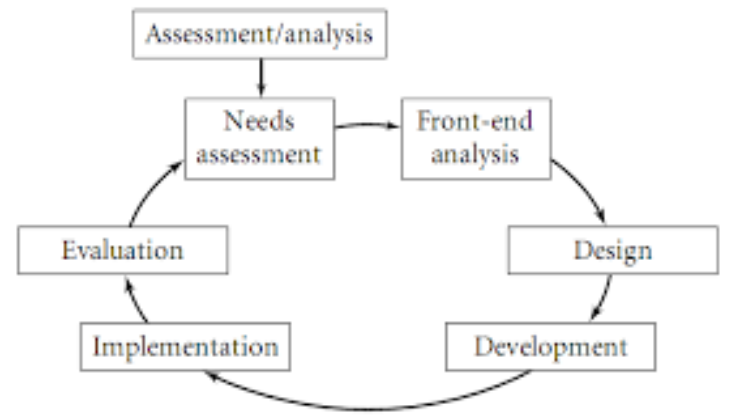

Gambar 1. Bagan Model Lee \& Owens (2004)

Prosedur penelitian dan pengembangan aplikasi berbasis android yang mendukung pembelajaran mobile atau bergerak ini disesuaikan dengan metode pengembangan Lee \& Owens (2004) yang dituangkan dan dapat dijabarkan sebagai berikut : (1) Analisis / Penilaian yang terdiri atas 2 bagian yaitu analisis kebutuhan dan analisis Front-End; (2) Desain; (3) Pengembangan; (4) Implementasi; (5) Evaluasi.

Tahap analisis terbagi atas dua bagian diantaranya analisis kebutuhan dapat dilakukan guna mengetahui kondisi siswa secara nyata serta kondisi yang diinginkan lewat metode observasi atau wawancara langsung. Analisis front-end dilakukan untuk menganalisa informasi yang lebih lengkap terkait produk seperti apa yang akan dikembangkan. Tahap ini dilakukan di SMAN 3 Lamongan khususnya pada kelas X Bahasa untuk mengetahui terkait permasalahan belajar, keadaan, karakteristik dan fasilitas sekolah yang nantinya akan menentukan arah pengembangan yang dilakukan.

Tahap desain menjadi tahap pengerjaan produk aplikasi yang akan dibuat mencakup desain tampilan, dan komponen lain yang terkait dalam pengalaman penggunaan. Pada tahap pengembangan produk aplikasi mobile learning "RecApps" menggunakan web-based application Thunkable X sebagai alat untuk membangung aplikasi dan Adobe Photoshop CC 2017 sebagai alat untuk mendesain tampilan dan berbagai komponen terkait yang nantinya akan diimport ke dalam Thunkable X. Sebelum tahap uji coba produk terhadap siswa, produk aplikasi terlebih dahulu akan di tanggapi oleh ahli media dan ahli materi untuk mengetahui kelayakan produk aplikasi mobile learning "RecApps". Kisi-kisi intrumen ahli media terdiri dari total 20 item pertanyaan sedangkan, untuk kisi-kisi ahli materi berjumlah 23 item dan untuk uji coba siswa berjumlah 22 item pertanyaan dengan menggunakan angket responden sebagai teknik pengumpulan data. 


\section{HASIL}

Penelitian dan pengembangan ini menghasilkan produk aplikasi mobile learning berbasis android bernama RecApps yang berfokus pada materi recount text pada mata pelajaran Sastra Inggris kelas $\mathrm{X}$ Bahasa. Aplikasi ini dibuat dengan desain yang simpel agar siswa dapat fokus pada isi materi yang disajikan di dalam aplikasi RecApps. Pemilihan warna dan font yang digunakan di dalam aplikasi dimaksudkan untuk meningkatkan keterbacaan isi dari segi kontras warna maupun keterbacaan jenis tulisan. Gambar 2. merupakan tampilan produk aplikasi mobile learning berbasis android "RecApps" pada bagian awal aplikasi, materi introduction recount text, dan materi grammar.

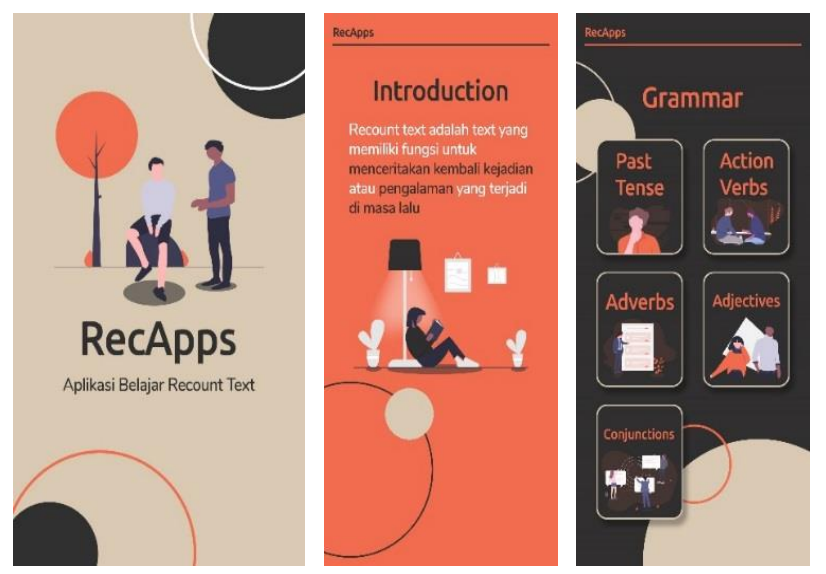

Gambar 2. Tampilan aplikasi RecApps

Tabel 1 merupakan data kuantitatif yang didapat dari hasil uji coba oleh ahli media yang ditujukan untuk mengetahui kelayakan produk aplikasi mobile learning "RecApps" terkait aspek desain, pengoperasian, dan interaksi. Dari data kuantitatif pada tabel 1. yang didapat dari hasil tanggapan ahli media pada aspek desain mendapatkan rata-rata sebesar 4. Pada aspek pengoperasian mendapatkan rata-rata skor sebesar 4, dan pada aspek interaksi mendapatkan ratarata skor sebesar 3,9. Dari hasil tanggapan ahli media diambil disimpulkan bahwa produk berupa aplikasi mobile learning "RecApps" layak untuk digunakan dalam pembelajaran di kelas.

Tabel 1. Tanggapan Ahli Media

\begin{tabular}{clcccc}
\hline No & Aspek & Jumlah Butir & Sangat Baik & Baik & Rata-rata \\
\hline $\mathbf{1}$ & Desain & 4 & 4 & 0 & 4 \\
\hline $\mathbf{2}$ & Pengoperasian & 6 & 6 & 0 & 4 \\
\hline $\mathbf{3}$ & Interaksi & 10 & 9 & 1 & 3,9 \\
\hline
\end{tabular}

Tabel 2 merupakan data kuantitatif yang didapat dari hasil uji coba oleh ahli materi yang ditujukan untuk mengetahui kelayakan produk aplikasi mobile learning "RecApps" terkait aspek kebenaran isi, perancangan materi, relevansi, dan konsep dasar materi. Berdasar pada data kuantitatif pada tabel 2. pada aspek kebenaran isi mendapatkan rata-rata sebesar 3. Pada aspek perancangan materi mendapatkan rata-rata sebesar 3,3. Pada aspek relevansi mendapatkan ratarata sebesar 3,4 dan, pada aspek konsep dasar materi mendapatkan rata-rata sebesar 3,4. Dari hasil uji coba ahli materi disimpulkan bahwa produk berupa aplikasi mobile learning "RecApps" layak untuk digunakan dalam pembelajaran di kelas.

Tabel 2. Tanggapan Ahli Materi

\begin{tabular}{clcccc}
\hline No & Aspek & Jumlah Butir & Sangat Baik & \multicolumn{1}{c}{ Baik } & \multicolumn{2}{c}{ Rata-rata } \\
\hline $\mathbf{1}$ & Kebenaran Isi & 2 & 0 & 2 & 3 \\
\hline $\mathbf{2}$ & Perancangan Materi & 9 & 3 & 6 & 3,3 \\
\hline $\mathbf{3}$ & Relevansi & 7 & 3 & 4 & 3,4 \\
\hline $\mathbf{4}$ & Konsep Dasar Materi & 5 & 2 & 3 & 3,4 \\
\hline
\end{tabular}


Data pada tabel 3 merupakan data kuantitatif yang didapat dari hasil uji coba lapangan kepada 17 orang siswa dengan total pertanyaan sebanyak 22 butir dan menilai produk aplikasi mobile learning "RecApps" pada aspek materi dan penggunaan. Pada aspek materi terdapat 10 item yang mana sebanyak 8 orang siswa menanggapi dengan Sangat Baik dan 9 orang siswa menanggapi dengan Baik serta memiliki rata-rata sebesar 3,5. Pada aspek penggunaan terdapat 12 item yang ditanggapi dengan Sangat Baik oleh 10 orang siswa dan Baik oleh 7 siswa lainnya dengan perolehan rata-rata sebesar 3,6.

Tabel 3. Tanggapan Siswa (audiens)

\begin{tabular}{|c|c|c|c|c|c|c|}
\hline No & Aspek & Jumlah Butir & Jumlah Siswa & Sangat Baik & Baik & Rata-rata \\
\hline 1 & Materi & 10 & 18 & 8 & 9 & 3,5 \\
\hline 2 & Penggunaan & 12 & 18 & 10 & 7 & 3,6 \\
\hline
\end{tabular}

\section{PEMBAHASAN}

Bahasa Inggris merupakan salah satu mata pelajaran wajib khususnya untuk kelas $\mathrm{X}$ penjurusan bahasa namun, dalam prakteknya penguasaan materi tersebut tidaklah mudah, butuh latihan terus menerus sehingga bisa menguasainya. Dengan adanya media pembelajaran sebagai penunjang pembelajaran siswa, diharapkan pembelajaran yang dialami siswa dapat lebih efektif.

Miarso (1984:48) menjelaskan bahwasanya media pembelajaran adalah segala sesuatu hal yang bisa dipergunakan guna merangsang pikiran, perasaan dan perhatian dari siswa. Menurut Brown (Dalam Wicaksono, 2018:134) "educational media types increasingly important roles in enabling stdents to reap benefits from individualized learning", dapat diartikan sebagai media semakin berperan penting untuk memungkinkan siswa mendapatkan benefit dari pembelajaran individual. Berangkat dari pemikiran tersebut diharapkan dengan pemberdayaan media dapat menghadirkan stimulus untuk siswa agar lebih bersemangat dalam memperbaharui pengetahuannya.

Hasil uji coba yang dilaksanakan oleh ahli media terkait dengan produk aplikasi mobile learning materi recount text "RecApps" menghasilkan data kuantitatif dari 20 item pertanyaan dengan 19 item ditanggapi Sangat Baik dengan nilai 4 dan 1 pertanyaan ditanggapi Baik dengan nilai 3. Ahli media menanggapi terkait 3 aspek yaitu, aspek desain yang terdiri dari 4 item pertanyaan, aspek pengoperasian yang terdiri dari 6 pertanyaan, dan aspek interaksi yang terdiri dari 10 pertanyaan. Pada aspek desain, ahli media menjawab semua dari 4 butir pertanyaan dengan (Sangat Baik). Pada aspek pengoperasian, ahli media meberikan tanggapan (Sangat Baik) pada seluruh 6 pertanyaan yang diajukan. Pada aspek interaksi, ahli media memberikan tanggapan (Sangat Baik) terhadap 9 butir pertanyaan dan menjawab (Baik) pada 1 pertanyaan dari total 10 butir pertanyaan. Selain itu, ahli media juga memberikan saran terkait aspek interaksi untuk menambahkan button setelah selesai materi sebagai tempat untuk siswa mengumpulkan tugas.

Hasil uji coba yang dilaksanakan oleh ahli materi membuahkan hasil berupa data kuantitatif dari 23 item pertanyaan. Pada uji coba ahli materi terdapat 4 aspek yang dinilai yaitu, kebenaran isi yang terdiri dari 2 pertanyaan, perancangan materi yang terdiri dari 9 pertanyaan, relevansi yang terdiri dari 7 pertanyaan, dan konsep dasar materi yang terdiri dari 5 pertanyaan. Pada aspek kebenaran isi, ahli materi menjawab keseluruhan pertanyaan dengan alternatif penilaian Baik dari total 2 item pertanyaan. Pada aspek perancangan materi, ahli materi menjawab dengan alternatif penilaian Sangat Baik untuk 3 item pertanyaan dan alternatif penilaian Baik untuk sisa 6 pertanyaan lainnya. Pada aspek relevansi, ahli materi menjawab dengan alternatif penilaian Sangat Baik untuk 3 pertanyaan dan alternatif penilaian Baik untuk 4 pertanyaan. Pada aspek konsep dasar materi, ahli materi menjawab dengan alternatif penilaian Sangat Baik untuk 2 pertanyaan 
dan alternatif penilaian Baik untuk 3 pertanyaan. Komentar yang disampaikan oleh ahli materi adalah kalau materi yang ada yang terkandung dalam produk pengembangan ini sudah sesuai bila disandingkan konsep dasar materi.

Setelah proses uji coba yang dilaksanakan oleh ahli media dan ahli materi selesai, dilakukan uji coba kepada 17 siswa kelas X peminatan bahasa yang ada di dalam SMAN 3 Lamongan. Uji coba yang dilaksanakan meliputi 2 aspek yaitu aspek materi dan aspek penggunaan yang keseluruhan terdiri atas 22 item pertanyaan. Pada aspek materi terdiri atas 10 item pertanyaan yang dijawab dengan alternatif penilaian Sangat Baik oleh 8 siswa, dan 9 siswa lainnya menjawab dengan alternatif penilaian Baik. Pada aspek penggunaan terdiri dari 12 item pertanyaan yang dijawab dengan alternatif penilaian Sangat Baik oleh 10 siswa dan 7 lainnya menjawab dengan alternatif penilaian Baik. Tanggapan yang diberikan siswa sangat positif, terkait dengan desain aplikasi yang dapat membuat siswa nyaman menggunakan aplikasi "RecApps". Berdasarkan hasil analisis data angket siswa yang disandingkan dengan kriteria kelayakan aspek penilaian, dapat dikatakan bahwa produk aplikasi mobile learning "RecApps" mendapat kualifikasi layak.

Ally (2009) memaparkan mobile learning adalah model pembelajaran yang dalam penggunaannya memerlukan perangkat seperti ponsel yang memungkinkan pembelajaran di lingkungan selain kelas yang mudah dibawa pada kondisi apapun dan kapanpun. Android merupakan operating system (OS) yang dipilih dengan beralasan bahwa android merupakan OS yang cenderung digunakan pada banyak perangkat seluler seperti smartphone dan tablet menurut Hendrawan (Dalam Nurhidayat, 2020). Mobile learning diharapkan menjadi sumber belajar guna menghadirkan kenyamanan belajar yang nantinya bisa berdampak pada peningkatan efektivitas dan efisiensi siswa pada proses penambahan pengetahuan mereka di masa sekarang maupun masa mendatang.

Konsep pembelajaran berbentuk mobile learning ini memanfaatkan ketersediaan materi dengan akses setiap saat juga memiliki visualisasi materi yang jelas (Listyorini, 2013). Tujuan mengembangkan mobile learning adalah untuk mempermudah belajar siswa di mana dan kapan pun, Karena memiliki karakteristik yang praktis di bawa kemanapun, maka mobile learning memiliki ketertarikan tersendiri (Panastha Agung, 2014). Surahman (2019) menjelaskan mobile learning digunakan guna alternatif layanan proses pembelajaran mengutamakan kemudahan, cepat, luwes, dan menarik tanpa mengurangi esensi terkait hakikat dalam pembelajaran pada umumnya. Mobile yang dihubungkan dengan internet, sudah pasti dapat menjelajah dunia informasi termasuk mencari bahan ajar yang mendukung (Majid, 2012).

Ally \& Prieto-Blázquez (2014) mengungkapkan bahwa pembelajaran seluler atau mobile learning dapat memberikan kesempatan yang sama bagi semua orang dengan memungkinkan pembelajaran yang bisa diakses dari seluruh zona waktu, sehingga bisa memperpendek lokasi maupun jarak. Menurut Rekkedal \& Dye (Dalam Surahman, 2017) mobile learning memudahkan siswa untuk belajar kapan saja dan dimana saja yang dengan strategi tersebut dapat memudahkan siswa guna memenuhi kompetensi materi secara utuh dengan waktu yang relatif lebih singkat dibanding media pembelajaran lainnya (Surahman \& Alfindasari, 2018).

Konten yang terdapat dalam aplikasi mobile learning berbasis android berisi materi tentang recount text pada mata pelajaran sastra Inggris yang membahas lebih dalam terkait apa itu recount text. Terdiri atas materi : (1) introduction yang membahas tentang pengertian, karakteristik dan jenis dari recount text, (2) structure membahas tentang bagian bagian yang membentuk sebuah recount text, (3) grammar membahas tentang tata bahasa yang digunakan dalam pembuatan recount text, (4) test berisi soal-soal latihan untuk menguatkan kembali pengetahuan siswa tentang recount text. 
Pada bagian akhir aplikasi yaitu pada bagian test disajikan variasi soal berdasarkan materi yang sudah dipelajari seperti soal tentang introduction, soal tentang adverbs, action verbs, ataupun tenses. Cara menjawab latihan soal tersebut dibuat dengan variasi model quiz, missing word, dan matchmaking sehingga siswa tidak bosan pada satu jenis variasi penjawaban soal saja. Setelah menjawab soal, siswa dapat mengetahui berapa skor yang didapat atau melihat peringkat pengerjaan soal mereka pada leaderboard yang akan dibandingkan dengan siswa lain berdasarkan jumlah jawaban yang benar dan lama waktu pengerjaan.

Penelitian sebelumnya yang juga senada dengan penelitian ini adalah penelitian dari (B.Rahardjo, 2019) yang menyimpulkan bahwa : "pembelajaran dengan memanfaatkan teknologi akan meningkatkan ketertarikan serta minat belajar". Hasil penelitian lainnya berasal dari Surahman \& Surjono, (2017) yang menghasilkan produk adaptive mobile learning yang terbukti bermafaat dan layak digunakan dalam pembelajaran dibuktikan dengan peningkatan hasil belajar sebesar 33,80. Penelitian berikutnya yang bernada sama berasal dari Rifai et al., (2020) yang mengembangkan produk mobile learning dan terbukti mampu membantu siswa mencapai tujuan pembelajaran dengan efektif dan efesien dibuktikan dengan hasil validasi kepada ahli media sebesar $96,25 \%$ dan $97,5 \%$ kepada ahli materi.

Penelitian yang dilakukan Putra et al., (2018) menghasilkan produk aplikasi mobile learning yang membantu siswa memahami langkah penulisan huruf hiragana dan valid menurut validasi kepada ahli media dan ahli materi. Martha et al., (2018) lewat e-book berbasis mobile learning menghasilkan e-book yang berisi video dan animasi sebagai visualisasi konsep abstrak untuk membantu siswa lebih memahami materi serta dengan mudah dapat dibuka dimanapun siswa berada. Penelitian yang dilakukan Saefi, (2015) menghasilkan produk media mobile learning berbasis android pada materi struktur dan fungsi sel mendapatkan kategori valid dan efektif dalam membantu siswa memahami materi serta mencapai tujuan pembelajaran.

\section{SIMPULAN}

Aplikasi mobile learning berbasis android "RecApps" materi recount text dinyatakan memenuhi kriteria layak untuk diberdayagunakan sebagai penunjang dalam pembelajaran Sastra Inggris khususnya materi recount text. Aplikasi mobile learning berbasis android "RecApps" ini dijadikan pemecah masalah pembelajaran yang memberikan ransangan agar siswa termotivasi dan dapat lebih semangat dalam proses pembelajaran. Berdasar tanggapan ahli media, ahli materi dan, uji coba ke siswa yang telah dianalisis menghasilkan data kuantitatif dengan kriteria layak. Kategori layak yang didapat selama proses uji coba dengan bukti jawaban oleh dosen ahli media, guru ahli materi serta beberapa siswa dengan nilai Sangat Baik bobot penilaian dinyatakan dalam angka 4 dan penilaian Baik dengan bobot penilaian dalam angka 3.

\section{DAFTAR RUJUKAN}

Ally, M. (2009). Mobile learning: Transforming the delivery of education and training. Athabasca University Press.

Ally, M., \& Prieto-Blázquez, J. (2014). What is the future of mobile learning in education? International Journal of Educational Technology in Higher Education, 11(1), 142-151. https://doi.org/10.7238/rusc.v11i1.2033

Fitriahadi, Dudi Romadhon, M Syaiful Harjendro, Toto Sidikoh, U. (2020). Pengantar Open Source dan Aplikasi: Konsep Pengembangan Produk Open Source. Teknik Penggunaan Sistem Operasi Linux dan Aplikasi Open Source. Nurul Fikri Press.

Kwon, S. K. (2019). The Impact of Including a British Accent in a National Listening Comprehension Test: Is it Fair? 영어교과교육, 18(3), 67-94. 
Lee, W. W., \& Owens, D. L. (2004). Multimedia-based instructional design: computer-based training, web-based training, distance broadcast training, performance-based solutions. John Wiley \& Sons.

Listyorini, T. (2013). Perancangan mobile learning mata kuliah sistem operasi berbasis android. Simetris: Jurnal Teknik Mesin, Elektro Dan Ilmu Komputer, 3(1), 25-30.

Majid, A. (2012). Mobile learning. Makalah Tidak Diterbitkan. Sekolah Pasca Sarjana (S-3). Bandung: Universitas Pendidikan Indonesia.

Martha, Z. D., Adi, E. P., \& Soepriyanto, Y. (2018). E-book berbasis Mobile learning. Jurnal Kajian Teknologi Pendidikan, 1(2), 109-114.

Miarso, Y. (1984). Teknologi komunikasi pendidikan: pengertian dan penerapannya di Indonesia (Issue 1). Rajawali.

Nurhidayat, B., Wedi, A., \& Praherdhiono, H. (2020). Pengembangan Multimedia Mobile Learning Berbasis Smartphone Android Materi Huruf Madura untuk SD Negeri 1 Perante Kabupaten Situbondo. JINOTEP (Jurnal Inovasi Dan Teknologi Pembelajaran): Kajian Dan Riset Dalam Teknologi Pembelajaran, 6(2), 103-110.

Panastha Agung, R. (2014). Perancangan Aplikasi Mobile Learning Untuk Pembelajaran Siswa Tuna Grahita Ringan di SDLB/C Terate Berbasis Android. Universitas Komputer Indonesia.

Prawiradilaga, D. S. (2012). Wawasan teknologi pendidikan. Jakarta: Kencana Prenada Media Group, 90033-90037.

Putra, R. A., Kuswandi, D., \& Husna, A. (2018). Pengembangan Mobile Learning Berbasis Smartphone Android Materi Huruf Hiragana Pada Pelatihan Bahasa Jepang SMA Ma'arif NU Pandaan. JINOTEP (Jurnal Inovasi Dan Teknologi Pembelajaran): Kajian Dan Riset Dalam Teknologi Pembelajaran, 4(2), 138-142.

Rahardjo, T., Degeng, N., \& Soepriyanto, Y. (2019). Pengembangan Multimedia Interaktif Mobile Learning Berbasis Android Aksara Jawa Kelas X SMK Negeri 5 Malang. Jurnal Kajian Teknologi Pendidikan. https://doi.org/10.17977/um038v2i32019p195

Riady, Sheila Claudy Riady Sentinuwo, Steven Karouw, S. (2016). Rancang Bangun Aplikasi Mobile Learning Anak Sekolah Minggu dengan Teknologi Augmented Reality Berbasis Android. Jurnal Teknik Informatika, 9(1).

Rifai, A., Sulton, S., \& Sulthoni, S. (2020). Pengembangan Media Mobile Learning Sebagai Pendukung Sumber Belajar Biologi Siswa SMA. Jurnal Kajian Teknologi Pendidikan, 3(1), $10-17$.

Rismadewi, N. W. M. (2019). Penerapan Model Creative Problem Solving Pada Guru Sebagai Upaya Meningkatkan Prestasi Belajar Siswa Pada Mata Pelajaran Bahasa Inggris. Indonesian Journal Of Educational Research and Review, 2(3), 302-310.

Saefi, M. (2015). Pengembangan media mobile learning berbasis android pada pembelajaran Struktur dan Fungsi Sel kelas XI. Universitas Negeri Malang.

Sumanto;, S. (2012). Model Pengembangan Media Pembelajaran SD. Kementerian Pendidikan dan Kebudayaan Universitas Negeri Malang.

Surahman, E. (2019). Integrated Mobile Learning System (IMOLES) Sebagai Upaya Mewujudkan Masyarakat Pebelajar Unggul Era Digital. JINOTEP (Jurnal Inovasi Dan Teknologi Pembelajaran) Kajian Dan Riset Dalam Teknologi Pembelajaran, 5(2). https://doi.org/10.17977/um031v5i22019p050

Surahman, E., \& Surjono, H. D. (2017). Pengembangan adaptive mobile learning pada mata pelajaran biologi SMA sebagai upaya mendukung proses blended learning. Jurnal Inovasi Teknologi Pendidikan, 4(1). https://doi.org/10.21831/jitp.v4i1.9723 
Surahman, E., \& Alfindasari, D. (2017, September). Developing adaptive mobile learning with the principle of coherence Mayer on biology subjects of high school to support the open and distance education. In 3rd International Conference on Education and Training (ICET 2017) (pp. 184-190). Atlantis Press.

Sutirman, M. P. (2013). Media dan model-model Pembelajaran Inovatif. Yogyakarta: Graha Ilmu.

Usman, M. U. (2006). Menjadi Guru yang Profesional. Bandung: Remaja Rosdakarya.

Wicaksono, M. A., Sihkabuden, S., \& Husna, A. (2018). Pengembangan Media Pembelajaran yang Berupa Suplement Pada Muatan Lokal Khas Ngawi. Jurnal Kajian Teknologi Pendidikan, 1(2), 133-140. 